\title{
Inspection Regulation between General Procedural Codification and Field Specifics - a Case Study of Slovenia
}

\author{
Polonca Kovač ${ }^{1}$
}

\begin{abstract}
Inspection, as the authoritative supervision of private liable persons to comply their activities with sector-specific laws, should ensure the full implementation of public policies. Slovenia adopted the Inspection Act (IA) in 2002, in order to conduct efficient inspection, and simultaneously guarantee the defence rights of the supervised parties pursuant to the fundamental principles of the EU, the national Constitution, and general Administrative Procedure Act. This article addresses the search for a balance between general codification and sector-related specifics as stipulated by the IA, applying normative, constitutional case law and comparative methods. Special attention is dedicated to the IA rules regarding participants, their legal protection and stages of respective proceedings. It has been concluded that the most of the IA specifics are justified in order to efficiently serve the public interest. This study reveals that the Slovene IA can represent a role model for efficient yet democratic supervision in other MS as well.
\end{abstract}

\section{Keywords}

Inspection, Administrative Procedure, Lex Specialis, Public Interest, Rights of Defence, EU Principles, Slovenia

\section{Introduction}

Administrative relations, even the more authoritative ones, pursue multiple goals: protection of human dignity, legal certainty, equality, transparency and accountability, flexible conciliation of interests, and efficient protection of the public interest in the sense of the consistent and full implementation of public policies. In such a context, procedure, and more specifically the regulation thereof, should serve several complementary functions. Considering the above goals, particularly the protection - at European and constitutional levels - of the fundamental rights of defence of the parties vis-à-vis administrative

\footnotetext{
${ }^{1}$ University of Ljubljana, Faculty of Administration, Gosarjeva ulica 5, SI-1000 Ljubljana, Slovenia. E-mail: polonca.kovac@fu.uni-lj.si.
} 
authorities, the rule-maker is hampered in the development of (special) administrative procedures. This applies all the more to administrative procedures where the authorities, in their supervisory function of protecting the public interest, interfere with the legal status of the parties regardless of or even contrary to their will.

Supervision in administrative relations may take different forms, but applies in all procedures. The terms »supervisory procedures « and, in particular, »inspection « used herein refer to procedures initiated ex officio and most often conducted in the form of investigations. ${ }^{2}$ The key element and the primarily protected category in such context is the public interest, or at least a potential collision between the legal interests of the supervised parties and the public interest as defined by sector-specific laws. Inspection, at least in Slovenia, is already by definition an activity in the public interest. It ensures compliance with the regulations, which is to the benefit of the society and individuals relying thereon based on the principle of legal certainty.

Most countries, as many as 22 in the EU-28, had developed a general administrative procedure act by 2015 (hereinafter: APA), Slovenia included. ${ }^{3}$ Limitations to and derogations from the general codification of administrative procedure are already admissible under the constitutional principle of equality and proportionality and because of the necessity of balancing public and private interests. As demonstrated by the good practices of various countries and the experience in individual administrative decision-making procedures, inspections as a form of administrative supervision require a specific approach. ${ }^{4}$ For this reason, Slovenia adopted a special Inspection Act (hereinafter: IA) in 2002. The IA, with 47 articles in total, applies to all inspection authorities, regardless of whether they operate at the state or municipal level, to all areas of supervision, and to all forms or types of liable persons (external or internal, private or public institutions, natural or legal persons). Sector-specific laws, the implementation of which is supervised under the IA, can govern the procedure differently, but this only rarely occurs in practice. The relation between the abovementioned acts is as follows: the APA is lex generalis whereas the IA is more specific vis-à-vis the APA yet still much more general than other field leges speciales - thus, it is said to be a »sector-specific general« act.

The topic of this article addresses two important aspects of legal theory. First, there is the issue of a relation between general and sector-specific codification. Namely, the study herein deals with research questions such as: to what extent can a sector-specific law

\footnotetext{
${ }^{2}$ Article 126 of the Slovene General Administrative Procedure Act provides: »The competent agency shall commence a procedure by virtue of its office if so provided by law or a regulation based on law, and if it establishes or learns that given the existing state of facts an administrative procedure must be commenced because of public interest. "This manner of initiating procedure normally derives from sector-specific legislation which specifies what public interest is and, possibly, also that the competent authority must initiate the procedure. In some areas, however, it derives from the very nature of things, e.g. in inspection, regardless of the subject-matter of supervision. See Pirnat (ed.) (2004).

${ }^{3}$ The Slovene APA follows Austrian tradition. It (still) contains as many as 325 articles and is pending modernisation in the sense of generalisation and transformation from inquisitorial procedure to service-orientation, while formalisation is necessary only as regards fundamental rights and the restriction thereof in the public interest. See, on the recent trends, Kovač (2011).

${ }^{4}$ Cf. Hofmann, Schneider and Ziller (2014). See in-depth analysis of general and sector-specific approaches in Auby (2014).
} 
(here: the IA) regulate procedures differently or complementary to a general one and simultaneously comply with the principle of the equal protection of rights, pursuant to the constitution and international principles in administrative law? Is it more effective to regulate procedural relations by general rules only or to allow special regulations, particularly when a higher level of collision is expected between interests, as in inspections? What are the individual special rules proved to be effective in the protection of public interest but still guaranteeing democratic and not excessive authority towards the liable parties? The field of inspection is of special relevance since it represents a strong need for public interest protection. Moreover, even in the classical authoritative administrative relations rather new approaches gain in importance. In sum, a legislator faces a dilemma: how to regulate procedures to exercise an efficient authority yet strive for more preventive and participatory relations towards supervised persons as in the past?

Second, a relation between general and special laws is transferred with similar questions as above to a relation between the EU and its legal order versus the national law of Member States (MS). In this context, Slovenia is analysed as an example of an EU MS. It aims to identify good practices and make further recommendations based on the obtained results. The study findings are based on the case of Slovenia and can therefore be used in any other country, especially those that follow a German-oriented administrative tradition. We believe these relations have so far mainly been studied only side by side. In this sense, the article predominantly addresses legal but also broader societal perspectives. Consequently, this article brings innovative insight and might initiate potential further research in this direction, in other countries or in other administrative fields.

After the initial introduction about the importance of uniform vis-à-vis diversified codification of administrative procedure, the article analyses the peculiarities of the IA in relation to the APA in terms of compliance with constitutional principles and safeguards under EU law. It builds on the hypothesis that the process specifics are either necessary or justified, while inspection is to be regulated uniformly, irrespective of the subject matter of inspection. The research question addressed herein is what kind of procedural arrangement - in terms of diversity or uniformity of rules irrespective of the type of procedure and subject-matter of supervision - is necessary for the effectiveness of public policies and compliance with European and constitutional safeguards of democratic authority. Several combined research methods apply, mainly dogmatic and normative analysis of case law, all embedded in a value assessment through axiological-deontological methods.

After a detailed examination of special procedural principles and rules by stage of procedure, the expected outcome of the analysis is that the optimal solution for an effective administrative supervision is a balance between equal procedural status of the parties in all administrative matters and the admissibility of a limited number of specifics depending on the goal and method of administrative supervision. Only the balance between effective implementation of public policies through the compliance with applicable administrative regulations and the provision of the rights of defence of the parties will allow the development of the concept of good administration. ${ }^{5}$

\footnotetext{
${ }^{5}$ More on the rights to good administration under Article 6 of the European Convention on Human Rights and
} Article 41 of the EU Charter of Fundamental Rights in Nehl (1999), Wakefield (2007), Meuwese, Schuurmans 


\section{Between equal procedural protection of the parties and effective protection of public interest}

Theoreticians and regulators at both national and European levels are constantly considering whether and to what extent administrative procedure, inspection included, is to be codified. Neither extreme is good and each has its own arguments pro et contra. Codification has a number of advantages, among which prevail the following two. First, operationalization of European ${ }^{6}$ and constitutional ${ }^{7}$ basic principles or safeguards by means of a procedural law. And second, the integration of administrative structures and special laws through uniform minimum standards, thus enabling transparency and equality and contributing to legal certainty and stability of relations. ${ }^{8}$ This applies to general codification either by means of the APA or a sector-specific general act, as in the case of inspection in Slovenia. At the same time, a certain degree of flexibility should be allowed to enable better implementation of sector-specific features and types of procedures (e.g. non-suspensiveness of appeal in the event of urgent inspection measures) as well as the faster adaptation of sector-specific laws to changes in society.

The two regimes - codification of general administrative procedure and procedural specifics in sector-specific laws - are necessarily complementary. ${ }^{9}$ In the search for balance, the ideal solution seems to be the approach pursued in the Slovene IA. Such an approach allows only limited derogations from the APA, but at the same time restricts - through common rules given the type of procedure and irrespective of the subject matter of procedure any unnecessary specifics in individual sector-specific acts. Such a codification may have its negative sides, but practice shows that positive effects prevail if regulation remains relatively general, thus allowing for flexibility in individual areas. This $\gg$ sector-specific general « codification serves several goals:

- the general principles of administrative relations or the special principles and rules complying with at least the majority of APA principles are still defined as fundamental;

and Voermans (2009), Hofmann and Mihaescu (2013), Bousta (2013), Helleringer and Purnhagen (eds.) (2014). On EU case law (EU and Council of Europe), see Auburn, Moffett and Sharland (2013).

${ }^{6}$ The Resolution of the European Parliament on a Law of Administrative Procedure of the EU of 2013 comprises nine fundamental principles: lawfulness, non-discrimination and equal treatment, proportionality, impartiality, consistency and legitimate expectations, privacy, fairness, transparency, efficiency and service, and ten rules and recommendations, most of them dogmatic at the level of principles, such as: the right to be heard, access to one's file, reasonable time limits, the duty to state reasons, indication of remedies. More in Meuwese, Schuurmans and Voermans (2009), Hofmann, Schneider and Ziller (2014), Dubos (2015).

7 The Constitution of the Republic of Slovenia (Articles 14 and 22) provides for equality before the law and equal protection of rights - regardless of the type of relation or procedure. Other principles highlighted in the Constitution include the use of language, the right to be heard, access to information, effective appeal, judicial control (Article 11, 22, 25, 157, etc., more in Šturm (ed.) (2011).

${ }^{8}$ Cf. Burgi and Durner (2012), Helleringer and Purnhagen (2014). See in particular Hofmann, Schneider and Ziller (2014): „Constitutional principles constitute decisive normative standards for the design of administrative procedures in the EU. The existence or non-existence of administrative procedural rules in the EU is not merely $a$ »technical « question, free of constitutional value choices. The realisation of constitutional principles has a considerable potential impact on substantive outcomes . . « Generally on sovereignty and EU integration, see Avbelj (2014). See Dubos (2015), on the theory of implied competences by the EU.

${ }^{9}$ Cf. Auby (2014), Kovač, Remic and Sever (2015), Galligan, Langan, and Constance (1998). 
- harmonisation and unification simplify the understanding of the users (parties), since very often the same subjects are involved in various matters in the same field (e.g. the same person is subject to various inspections);

- possibility of adaptation by type - if not by field, at least by method of work in supervision - and introduction of measures to better protect public interest and the rights of third parties that have been violated by the liable person.

A similar practice can be observed in other countries and in the EU, for instance in relation to public charges and assistance or the issuing of various environmental permits. ${ }^{10}$

Equal protection of rights does not mean that a sector-specific act could not regulate a relation or a procedure otherwise. Yet also in such case it is advisable to follow the principle of proportionality in the sense of minimum derogation from the general regulation, i.e. the APA. Likewise, the differing regulation should not be arbitrary or lack reasonable or objective reason. This is known as the de minimis rule, whereby general provisions - in spite of the precedence of leges speciales - constitute, at least as regards fundamental principles and rights, a minimum standard that special acts cannot annul or can only exceptionally override. Rule-makers should therefore also pursue the fundamental principles of administrative relations in every special field, while the rules may differ depending on the level of conflictuality of the relation and the need for efficiency as regards the objective of the procedure. ${ }^{11}$

However, economy in the sense of cost reduction does not suffice. ${ }^{12}$ What truly matters is the legitimacy of the objective of substantive law. Therefore, a »sector-specific general « act should only regulate what is different than under the APA and is only reasonable if a critical mass of necessary and justified specifics is defined. Thus, even when conducting procedures in a specific administrative field, there should be neither too many nor too little specific rules.

\section{Analysis of the specific features in the procedural regulation of inspection in Slovenia}

\section{Trends and dilemmas of inspection procedures in Slovenia and broadly}

The »primary« responsibility for compliance with the regulations lies with the parties themselves, while the supervision agency bears (only) a secondary responsibility for the situation in a certain field. Yet, an efficient mechanism of authority and responsibility includes both functional and ethical aspects. The first is to ensure the efficiency of public policies with public interest under applicable regulations, while the latter is to provide for their reliability on moral standards, both in the functioning of the administrative system

\footnotetext{
${ }^{10}$ More in Nehl (1999), Wakefield (2007), Burgi and Durner (2012), Tolsma (2014).

${ }^{11}$ Cf. Nehl (1999), Harlow and Rawlings (1997), Statskontoret (2005).

12 In such regard, see the judgement of the Court of Justice Grauel Rüffer vs. Pokorná (C-322/13, March 27, 2014), whereby the claims of the defendant state Italy concerning additional costs that would arise from the compliance with the right to use the German plaintiff's own (minority) language, are not justified since »aims of a purely economic nature cannot constitute pressing reasons of public interest justifying a restriction of a fundamental freedom $\ll$.
} 
and as regards individual (particularly supervisory) authorities and officials. Therefore, throughout the world, in addition to the usual repressive function of supervision which pursues the protection of public interest, increasing emphasis is placed on collaboration and, more generally, conflict prevention. ${ }^{13}$ In this context, inspections act as systemic improvements' drivers, enabling policy makers to prepare better de lege ferenda regulation. Irrespective of the development trends of a more partnership-driven supervision, this area in Slovenia presents, owing to the primary protection of the public interest, several peculiarities that are regulated by sector-specific laws. These refer to:

1. the specific provisions of sector-specific laws (or acts issued on the basis thereof) regulating an institution or part thereof differently than the APA; or

2. sector-specific laws regulating the same institution as the APA, but in more detail or complementary to the APA (see Table 1).

Looking at sector-specific provisions more carefully, one notices that there are actually fewer peculiarities than it seems at first glance, since quite often sector-specific regulations name the participants and the acts otherwise but actually refer to the classic APA institutions and rules.

\section{Table 1: Classification of the IA procedural provisions vis-à-vis the (general) APA}

\begin{tabular}{|c|c|c|}
\hline $\begin{array}{l}\text { Different than the APA } \\
\text { (example and article) }\end{array}$ & $\begin{array}{l}\text { Complementary to the APA } \\
\text { (example and article) }\end{array}$ & $\begin{array}{l}\text { Only seem different than the APA } \\
\text { (example and article })^{14}\end{array}$ \\
\hline $\begin{array}{l}\text { powers (18, etc.), drawing up and } \\
\text { delivery of the inspection record } \\
(29) \text {, measures }(7,32-36) \text {, } \\
\text { inspection costs }(31) \text {, } \\
\text { non-suspensive effect of appeal } \\
(30) \text {, etc. }\end{array}$ & $\begin{array}{l}\text { principles (4-7), conditions } \\
\text { and status of inspectors } \\
(12-17,37) \text {, partial powers } \\
\text { (entry into premises, taking } \\
\text { samples, 19-23), notifications } \\
(24,36) \text {, etc. }\end{array}$ & $\begin{array}{l}\text { principle of subsidiarity (3), the } \\
\text { applicant as party to the } \\
\text { proceeding, dealing with reports } \\
\text { (24), termination of the procedure } \\
\text { by record/decision (28), etc. }\end{array}$ \\
\hline
\end{tabular}

Source: own analysis

Given the peculiarities of the supervisory procedures, sector-specific laws - the IA included - quite often lay down special principles which, with due consideration of Article 22 of the Slovene Constitution, may not prejudice or impair the fundamental principles provided by the APA. However, they are more than just specific principles applying to the specific stages of the procedure. In fact, they may be considered the »basic sector-specific « principles and as such complement the fundamental principles of the APA.

In inspection procedures in Slovenia, the above implies a complementary application of 13 (four under the IA and nine under the APA) fundamental principles. In supervisory procedures, special emphasis is generally placed on the principle of proportionality (Article 7

\footnotetext{
${ }^{13}$ See on elaboration of ADR in administrative matters by country profiles and convergence findings in Europe in Dragos and Neamtu (eds.) (2014). See Kelly (2003), elaborating inspections as holding a crucial role in creative policy making.

${ }^{14}$ According to the above classification, general rules under the APA should not be entered in the special (although general) laws, regardless of content. In addition to the lack of transparency, there is a risk that the remaining rules might be interpreted a contrario, i.e. as non-applying. Likewise, the different terminology used in sector-specific laws might lead to the erroneous interpretation that the remaining provisions of the APA in relation to a particular institution do not apply, which must subsequently be dealt with in a judicial dispute.
} 
of the IA). The principle of proportionality has both a substantive and a procedural dimension - it is necessary to weigh between different interests and possibilities of action not only in the final decision but also as regards the manner in which the procedure is conducted, for instance in the economical choice of evidence. Under the IA, and frequently also under sector-specific laws, proportionality reflects in the grading of such measures. ${ }^{15}$ Data on the operation of the inspections in Slovenia are collected through the Inspection Council, which coordinates all 25 national inspection authorities. The national inspection authorities employed a total of approx. 1,450 inspectors in 2014, with the biggest shares operating in tax (440) and in food (282) inspections. The average number of inspections carried out per inspector was 71 in 2013 and 83 in 2014. However, the Inspection Council monitors the work of inspection authorities only in quantitative terms, such as number of inspections, number of issued decisions, number of imposed fines. The 2014 Annual Report of the Inspection Council listed above all (otherwise 11 in total) the following indicators: number of inspections and offence cases per capita, share of solved cases. There are only a few indicators with at least a partial value component, such as the success rate of appeals, but it is enough to realise there are some key differences between them (e.g. the average share of justified appeals is $1 \%$, in fiscal and labour inspection around $10 \%$ ). The indicators taken as a whole are defined only quantitatively and thus only partially enable the efficiency of supervision to be assessed. Despite some criticism concerning the lack of comparability by field or changed methodology, it can be concluded that the work of inspection authorities is becoming increasingly effective. Yet it is possible to claim so (only!) because over the past year more inspections were carried out and more measures imposed (see Table 2). However, there are no indicators (yet) showing whether and to what extent the liable parties act more legitimately and coherently as a result of inspection, which is after all its main goal.

Table 2: Data on the work of national inspection authorities in Slovenia in 2007, 2013 and 2014

\begin{tabular}{|c|c|c|c|}
\hline Indicator & 2007 & 2013 & 2014 \\
\hline No. of inspections (reviews) & 188,937 & 562,730 & 519,097 \\
\hline No. of imposed measures by individual acts & 66,554 & $\begin{array}{l}84,995 \\
\text { of which } \\
55,262 \text { administrative } \\
29,733 \text { offence acts }\end{array}$ & $\begin{array}{l}83,328 \\
\text { of which } \\
53,134 \text { administrative } \\
(4 \% \text { less as in } 2013) \\
30,194 \text { offence acts } \\
(2 \% \text { more as in } 2013)\end{array}$ \\
\hline
\end{tabular}

Source: Inspection Council-Annual Reports

As is evident from the above table, one of the basic dilemmas and the most difficult question regarding supervision in Slovenia is when it involves an administrative relation and thus an administrative procedure, and when it involves a different form of supervision,

\footnotetext{
15 Thus, an inspector cannot be reprimanded for disproportionate application of a measure if he bases his action on a sector-specific law which lays down a certain measure depending on the grade of incompliance (see Administrative Court of the Republic of Slovenia (hereinafter: AC), I U 1735/2010, June 9, 2011). Proportionality is expressed also in the setting of a grace period, i.e. (inversely) proportionate to the threat to public interest, and a period of execution (AC, I U 924/2012, October 2, 2012).
} 
such as offences. Slovenian inspectors have gained competence over offence procedures only in 2005 in order to act against the parties more decisively and more efficiently and thus better protect public interest. ${ }^{16}$ However, the fine alone is not enough to force a party to comply with the law. Therefore, an administrative measure requiring, e.g. the elimination of non-compliance or cessation of activity is imperative - contrary to trends in recent years revealed in Table 2. I believe that, given the systemic function of inspection, when in doubt one should agree to the interpretation that the inspector acts primarily with an administrative measure to establish a legally required situation by a party, and never only in an offence proceeding to merely sanction a party since an unlawful situation might remain as such. Also, practice shows that a paid fine does not mean that the liable party will eliminate the underlying breach of the regulation, which means that they can continue to cause damage to third parties, the environment, safety, and to other otherwise legally protected categories.

However, the issue becomes most pressing when both administrative (e.g. inspection) and offence supervisions are to be carried out simultaneously. These two relations in fact differ as regards a few basic guarantees (provided also under international and constitutional law) to such an extent that even in the event of the same authority or official, the same party and the same facts, it is impossible to legally and at the same time effectively carry out both the administrative and (!) offence proceedings. Namely, in an administrative procedure, the party is obliged to tell the truth (Article 11 of the APA, based on the protection of the public interest and material truth), while in offence proceedings the party has the privilege against self-incrimination under Article 29 of the Constitution and the obtained evidence can thus be deemed inadmissible. ${ }^{17}$ Hence, if the party is provided with punitive guarantees, the administrative procedure is unlikely to effectively protect the public interest, although this is the primary purpose of (administrative) supervision. Regulations, particularly in the context of inspection as well as other forms of supervision, should in fact be revised de lege ferenda so that the law would already determine when to give precedence to the one, and when to the other, principle and right.

A special form of administrative supervision is carried out by regulatory agencies ${ }^{18}$ when resolving disputes between the providers of public services or distributors or holders of certain public rights (e.g. the collective administrators of copyright) and their users. This is not the »classic « protection of public interest against the private interest of the party since the dispute before the administrative agency primarily involves two parties with private interests (e.g. a telephone operator and a subscriber). Yet, it is - somehow indirectly - in the public interest to settle the dispute. In such a case, given the obvious actual (market, factual) predominance of one party (telephone operator) over the other (subscriber), in the procedure before the relevant supervisory agency the state will protect the weaker

\footnotetext{
${ }^{16}$ More on related grounds and dilemmas and case law in Kovač, Remic and Sever (2015).

${ }^{17}$ See judgements of the Supreme Court of Republic of Slovenia (SC), IV Ips 117/2008, March 9, 2009, and Constitutional Court (CC), Up-1293/08, July 6, 2011, as to which safeguards should have precedence if, in the same life situation, the inspector acts administratively or punitively.

${ }^{18}$ E.g. Energy Agency or Post Agency, similarly also the Intellectual Property Office under the Copyright and Related Rights Act. Compare for EU and USA in Meuwese, Schuurmans and Voermans (2009).
} 
party, thus ensuring that the dispute is treated more equally. Relations between the consumers/users of such services and the providers are known under EU law as »services of general interest « or »universal service obligation «, and thus considered as administrative matters that fall under public (administrative) law. Luckily, these procedures imply a number of special rules, largely based on the possibility of an amicable and rapid settlement of the dispute, e.g. including the finality of the first-instance decision.

The above is not only a characteristic of regulatory agencies in the European liberalised markets. Quite often, overlapping in terms of protection of public and private interests also occurs in inspection in its narrower sense. Typically, such is the case where the inspection service is at least indirectly competent for supervision in the relations between two or more private parties, e.g. labour inspection in a dispute between the employer and the employee, market inspection in a dispute between the manufacturer/supplier and the consumer, personal data inspection in a dispute between the (private) administrator of a database and the holder of such data, or school inspection intervening between the school and the parents. Primarily, of course, the parties in such inspections are the liable persons, namely employers, suppliers, administrators and schools. The »other side« acts as the reporting person or even as an accessory participant in the administrative inspection procedure. This raises the question as to whether the subject-matter of administrative procedure is solely the public interest or also the protection of private interests if the liable person, by violating the regulations, interfered with the legal status of the other party. The dilemma is indeed present, considering that the Slovenian legislation provides for the »double« protection of adversely affected persons - through litigation in the court and through (a request for) inspection, since sector-specific laws often regulate the relations unclearly or with at least apparent overlapping.

I believe that in the above situation, the special regulations should be considered from the viewpoint of the legal and administrative system of the country. This means that if the rule-maker decides to protect an otherwise private relation under public law, it thereby defines a sector-specific public interest although the latter corresponds to a private interest of the parties to the dispute. In such a case, supervisory agencies must recognise the status of accessory participants or interveners to the adversely affected persons (if their interest is also truly individual and private and existing at the time of supervision), as well as provide an interpretation whereby the administrative agency (in our case, inspectorate) is obliged to conduct an administrative procedure also to resolve a dispute between two otherwise private parties. In such cases, although conducted by an inspectorate, the procedure will not be a »classic « inspection procedure ex officio but one conducted on the request of the affected person. In an inspection procedure, the affected person will have the status of accessory participant only if the same legal interest cannot be claimed otherwise, that is in a different administrative ${ }^{19}$ or judicial procedure.

\footnotetext{
${ }^{19}$ Cf. SC in the case I Up 595/2004, September 21, 2005, claiming that the parents of a child with special needs can claim legal interest in the procedure of granting such status to the child, and are therefore not recognised the status of accessory participants in the inspection procedure over the school attended by the child and allegedly violating the child's rights.
} 


\section{Participants in the inspection procedure - inspectors, liable persons and accessory participants}

Due to its specific nature in terms of subject-matter and methodology, supervision is most often carried out by specialised supervisory agencies or authorities that operate at both national and local government levels. Their jurisdiction ratione materiae is thus determined by a sector-specific law or government decree, while territorial jurisdiction extends to the entire territory of the state although the agencies have regional branches. Pursuant to the IA, the supervisory agency is usually an inspectorate or other semi-autonomous body within the ministry.

As far as the actual organisation of inspection authority in Slovenia is concerned, a two-fold concept applies. After the first concept, the inspection agency operates within a body within a ministry that exercises supervision and conducts procedures ex officio while at the same time performing several other tasks in the relevant field. ${ }^{20}$ The organisation in agencies and similar bodies is identical. ${ }^{21}$ The second, prevailing concept involves the organisation of inspection authorities following a functional principle, although still within a ministry, i.e. with a specialised inspectorate within the line ministry. ${ }^{22}$ Both concepts have their strengths and weaknesses, but most arguments speak in favour of the second one based on specialisation by the type of tasks and procedures. Basically, inspection authorities carry out a predominantly repressive function, which means they need to be kept separate from other parts of the administration. ${ }^{23}$ Even more significantly, having regard to Articles 4, 8 and the following of the IA, it is imperative to respect the principle of independence of the inspection authorities and inspectors, namely its autonomy in relation to politics (political government and ministers). The idea that the inspectorate operates as an independent body or at least within a specialised agency that is not directly subordinate to a minister finds support in the provision of professional decision-making outside the political influence of a minister.

As regards the status of inspectors, such must be distinguished from the status of other officials. Articles 12-19 and 27 of the IA lay down special requirements for inspectors (appropriate education, professional examination for an inspector, etc.), as well as their powers and responsibilities (especially for damage). It is important to underline that the more stringent requirements are balanced with major powers. In fact, to have more powers vis-à-vis the parties, inspectors need greater knowledge and responsibility. The IA also provides for the independence of any inspector who is to deal with a specific case in its entirety. Independence means the inspector has full powers that neither the chief inspector nor the head of inspection in a specific case can interfere with. And if an inspector acts contrary to the law, for which the chief inspector is indirectly responsible, the IA provides special disciplinary and similar provisions.

\footnotetext{
${ }^{20}$ E.g. the Administration for Food Safety, with most of its employees, such as »official veterinarians«, acting as inspectors.

${ }^{21}$ E.g. the Information Commissioner, which oversees the protection of personal data, also employs other persons for other types of work.

${ }^{22}$ E.g. Health Inspectorate within Ministry of Health or Market Inspectorate within Ministry of Economy.

${ }^{23}$ Pirnat (ed.) (2004).
} 
The party in an inspection procedure is normally the "person liable « to comply with the regulations. The status of the party is determined in accordance with the relevant sectorspecific law as real legitimacy must be defined under substantive law. ${ }^{24}$ However, case law reveals multiple problems in relation thereto, since the criterion for liability should be the actual violation, rather than, e.g. the necessary registration of a certain activity. ${ }^{25}$ If such is not the case, the biggest offenders are likely to evade the inspection measures. A further problem that emerges in practice is that legitimacy is considered to be a factor of competence. Just like other procedural assumptions, competence must be determined prior to the start of the procedure and not as a result of the outcome of fact-finding. ${ }^{26}$

However, most problems in Slovenia arise in relation to accessory participants or, more generally, reporting persons and initiators. This stems from administrative and judicial practice, even though at least in case law the narrow interpretation whereby in supervisory procedures the status of a party only pertains to the liable person has been exceeded. In fact, notwithstanding the explicit provision of Article 24 of the IA concerning the reporting person, legal interest may also be found elsewhere than merely in the regulation governing the decision or a general (sector-specific) act. As shown by the analysis of case law for the period 2003-2013, approximately 100 major cases are published) at all levels of judicial review most disputes relate to the status of the reporting person (about $65 \%$ of all disputes). The majority of disputes arise in construction, which is understandable given the high level of conflictuality in relations between neighbours.

Figure 1: Share of disputes by IA chapter or issue in question in judicial dispute and type/ instance of court (AC as Administrative Court, SC as Supreme Court and CC as Constitutional Court of the Republic of Slovenia)

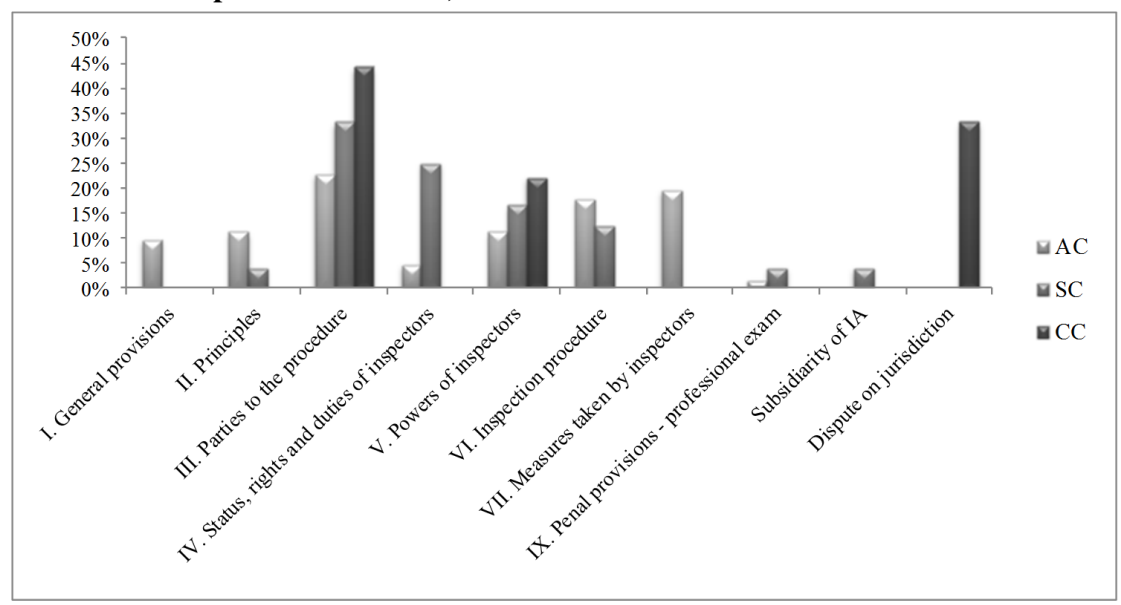

Source: selection from Kovač, Remic and Sever (2015)

\footnotetext{
${ }^{24}$ Androjna and Kerševan (2006).

${ }^{25}$ According to Administrative Court, AC, IU 475/2013, June 11, 2014, and IU 42/2013, January 29, 2014.

${ }^{26}$ For instance, in a case involving illegal waste, the Environmental Protection Act will attribute competence to various inspection authorities, depending on the owner and type of illegal waste.
} 
According to case $\operatorname{law}^{27}$, reporting persons may act as accessory participants if they are adversely affected in the given case, usually by a violation committed by the liable person or by a measure taken by an inspector. Considering the specific provisions of the laws that preclude accessory participants, from the viewpoint of the equal protection of rights under Article 22 of the Constitution, such interventions are rarely consistent and proportionate. Thus, the Constitutional Court (hereinafter: CC) may annul such provisions (e.g. CC, UI-165/09-34, March 3, 2011 in conjunction with Articles 23 and 25 of the Constitution on effective appeal and judicial protection) or interpret them complementarily to the restrictive act.

\section{Phases in the inspection procedure and legal protection}

The first procedural issue to be raised in the field of supervision concerns the initiation of the procedure. The dilemma is whether such a procedure should be initiated only ex officio, or can - in specific circumstances - be requested by the party itself. Of course, it is unlikely that the party would prioritise the public interest over their own interests. However, this seems to be the case in supervision, although most probably the party would not require the initiation of procedure for the sake of public interest and contrary to their own interests, but rather because of their own interests in the sense of outwitting the public interest. If they report themselves, the parties have the opportunity to prepare for the inspection and make sure they will not be supervised again in the future, as it is not possible to decide twice on the same case. The possibility of initiating a procedure (inspection) at the request of the liable person is, in my opinion, inadmissible, since supervision is to be carried out in the public interest or for the protection of third parties (SC, I Up 605/99, March 26, 2003). In practice, the system could at some point become overwhelmed with requests made either by the liable persons or by banks or business partners requiring the review as a kind of credit. Thus, for example, it is, also for pragmatic reasons, not admissible to initiate tax inspection at the request of the taxpayer.

As regards the initiation of the procedure ex officio, a common dilemma is when to consider the procedure to have been initiated. This is closely related to the provision of the rights of the parties (e.g. the right to be heard) and to several other rules, concerning, e.g. the beginning and end of the period necessary for issuing a decision. The dilemma arises particularly when the procedure is not initiated by a decision, as in the case of tax inspection. If we followed the strict interpretation that the first procedural step has already been taken when an administrative matter is entered in the records, for example upon the receipt of a report, we would eventually end up with a myriad of procedures that make no sense at all, as it could soon be established that there is not even a suspicion of a violation. In my opinion, the procedure starts if and when the first procedural act is taken in relation to the party (!), for example by convening a hearing, by appointing an expert, or by inspecting the liable person's premises or papers. The first procedural act can also be a request to transmit information to another agency (IU 1609/2013, February 13, 2014) or,

${ }_{27}$ Both AC and CC, e.g. Up-3/97, July 15, 1999, Up-257/03-9, October 2, 2003, U 2283/2002, November 6, 2003, U-I-153/01, February 12, 2004, Up-2411/06-12, May 22, 2008, II U 180/2012, April 10, 2013. 
more so, the record of the inspection (X Ips 775/2006, May 21, 2008), of which the liable party should be informed in order to prepare defence. Likewise, the inspector's statement that the inspection has not shown any violation of the regulations does not suffice to prove that the procedure has been initiated (and completed). If, for example, an inspection has been carried out only to verify the eligibility of the report, this does not mean that the procedure has actually been initiated.

Specific rules concerning procedural acts often refer to the record of inspection under Articles 29 and 33 of the IA or to the record of tax inspection under Article 140 of the Tax Procedure Act. These special rules generally provide more powers for the inspectors and less rights for the parties than the APA. Logically, one could question whether such rules are constitutionally proportionate even if supervision per se is carried out in the public interest. Article 29 of the IA, for instance, interferes with the constitutionally provided rights to participation and defence under the APA since it allows that the inspection record is drawn up even without a representative (or statutory representative) of the liable person being present, and served directly on the premises of the liable party as the site of inspection. The same is suggested by the judgements of the AC, IU 1239/2009, June 30,2009 , in the field of building inspection, and IU 1184/2010, January 12, 2011, in the field of inspection of personal data protection. In my opinion, Article 29 of the IA should be revised so as to enable the equal legal status of natural and legal persons and a (more) balanced participation of the liable person (than under the APA). Thus, also under the IA, liable persons could only be precluded by an inspector's power to obtain evidence in their absence, regardless of their status, if clear and present danger is in question or they avoid cooperation in the procedure.

In case UI-40/12-31, April 13, 2013, the Constitutional Court held as excessive the provisions of the Prevention of Restriction of Competition Act, arguing that - given the constitutional protection of privacy - the relevant agency cannot invoke the power to inspect business premises which are not open to the public without the party's consent or a court order. If such a decision is extrapolated to the entire supervision, we can justifiably ask ourselves whether the weighing was carried out adequately in the light of the public interest being a protected category in supervision, or whether such interpretation of the safeguards enshrined in Article 36 of the Constitution implies an a priori ineffective inspection.

Following sector-specific laws, supervisory procedures often terminate with a particular type of act being issued to support the specifics of the field or the measures imposed. Nevertheless, those acts must be interpreted systemically, i.e. regardless of the potential specific name or form and the implications by a special law for the party. For example, although they may be formulated as »records « under Article 28 of the IA, they must contain a decision about the termination of the procedure since only an individual administrative act (and not a declarative record) can have legal implications. Another problem is that certain measures prescribed under the IA are at least to some extent misleading, in the sense of failing to distinguish between subject-matter and form. ${ }^{28}$ Similarly problematic is

${ }^{28}$ For example, it is not clear that the special measures and measures to protect third parties referred to in Articles 32-36 of the IA are imposed by means of an administrative decision, since the IA only defines the subject-matter 
the question of the legitimacy of the measures (Article 32 of the IA) if the sector-specific law is unclear or indeterminate in defining the subject-matter or direction of the measure. I believe that in such a case the inspector may and must opt for a measure which will, in terms of subject-matter, follow a contrario the interpretation of the sector-specific law as to what the duty of the liable person is. Given a few rulings that annulled the acts of inspectors before the court for having allegedly exceeded their powers - in the sense that the sector-specific law did not define the given measure and the inspector should therefore not have imposed it (although he only imposed what the sector-specific law actually required from the parties) ${ }^{29}-$ Articles 3 and 32 of the IA were supplemented in 2014. A measure must now also have a defined deadline (to fulfil the obligation). According to the APA and case law, ${ }^{30}$ the decision is otherwise non-enforceable and thus considered null and void according to Article 279 of the APA. Such deadlines cannot be extended, except in the case of specifics of a sector-specific law. To conclude, it needs to be underlined that, in the case of inspections, the imposition of a measure most often does not suffice and a forced execution is necessary to satisfy the public interest.

Very often, particularly in supervisory procedures, remedies are regulated differently or complementary to the APA. In the light of the constitutional principle of equal protection of rights, the most stringent measure is exclusion of the appeal (e.g. in the case of agencies which appear as quasi-judicial bodies) or the non-suspensiveness thereof, which is otherwise an ordinary remedy under Article 13 of the APA. However, in particular in the administrative relations, non-suspensiveness seems to be an even more stringent measure than the exclusion of the appeal, considering that it is an element of effectiveness of the legal remedies under Article 25 of the Constitution, while in the event of exclusion, the function of appeal can be assumed by the administrative dispute. ${ }^{31}$ Apparently, the Constitutional Court has thus also recently begun to address the peculiarities of the field more strictly. Namely, in case UI-313/13-88, March 25, 2014, the Court repealed an entire law, mainly basing its arguments on restrictive elements concerning the limited reasons for appeal and thus ineffective legal protection and access to justice.

It can be concluded that just the right amount of balance is needed between the general codification of procedural norms and specific regulations. This is particularly necessary in order to protect international or European and (national) constitutional principles, such as the rights of defence of persons adversely affected by the authorities. In administrative supervision (inspection in particular), this results in a limited eligibility of certain specific

of the measure (e.g. a ban on the provision of electricity or publication of a decision).

${ }^{29}$ E.g. labour inspection, cf. Pirnat (ed.) (2004). As regards these rulings, it needs to be underlined that they nevertheless allowed an alternative legal basis for a measure, e.g. U 1236/93, March 29, 1995: »The market inspectorate cannot base its decision only on the provision of the IA if it does not have powers under substantive law for specific measures or at least clearly defined duties of persons subject to supervision by the inspector. ". According to AC, U 1060/2001, March 12, 2003, the explicit basis for a measure must be incorporated in the law when the measure imposed by the inspector interferes with a constitutional right of the supervised person (e.g. Article 74 of the Constitution on free economic initiative).

${ }^{30}$ Cf. SC, case II U 454/2013, March 12, 2014, about a veterinary inspection decision where no deadline but only the measure was imposed (in this case: observing the dog to prevent further attack - but until when?).

${ }^{31}$ As followed in Slovenia since U-I-219/03, December 1, 2005. 
provisions vis-à-vis the general regulation under the APA, in order to effectively protect the public interest and the affected parties.

\section{Conclusion}

The normative analysis of the Slovene IA and APA and case law concerning subsidiarity and equal protection of rights roughly leads to two conclusions. First, the initial hypothesis claiming that inspection should be regulated - even if partly differently than under the APA - uniformly and irrespective of the field of inspection, can be confirmed. However, it is not possible to fully confirm the first part of the hypothesis, claiming that the procedural specifics of inspection are - given the Slovene IA - necessary or at least justified by the existence of the constitutionally required substantive reason for a regulation that differs from the APA. Administrative practice and case law reveal that problems already exist at the level of regulation, for example, under the IA the a priori exclusion of accessory participants from inspection, the limited rights of participation in inspection, and unfounded distinction between different statuses of liable persons. Even more problematic is the implementation of constitutionally consistent norms which, given an apparently different regulation (e.g. concerning the form of completion of the procedure and the consequent legal implications), lead to systemic problems in practice. Thus the inspectors, when they consider a report unjustified, issue only records rather than individual administrative acts against which the affected parties could file an appeal or lawsuit. On the other hand, the comparative analysis shows ${ }^{32}$ that the IA could, in certain respects and consistent with the Constitution, further increase the special procedural protection in relation to the parties. One such possibility is the exclusion of appeal, which for the parties is even less invasive than the non-suspensiveness of appeal under the IA.

Generally, it can be concluded that the uniformity of general principles and rules allows - also for the subtype of administrative relationships such as supervisory procedures a win-win solution. The optimal regulation seems to be a very general APA and a slightly more specific and operational IA, the purpose of which is not to derogate from the APA but rather to ensure uniform action by inspection authorities at all levels of government and in all fields of supervision. Such sector-specific yet still general codification in fact establishes - alongside the de minimis rule under international, constitutional and APA standards - a balance which is to be achieved by a democratic and simultaneously effective state or public administration.

\footnotetext{
32 By ReNEUAL; Hofmann, Schneider and Ziller (2014). Cf. for the Netherlands Ortlep, Ouden, Schuurmans,
} Tollenaar, Veen and Wolkswinkel (2014). More generally, Rose-Ackerman and Lindseth (2011). 


\section{References}

Androjna, V. and Kerševan, E. (2006). Upravno procesno pravo [Administrative-Procedural Law]. Ljubljana: GV.

Auburn, J., Moffett, J. and Sharland, A. (eds.). (2013). Judicial Review. Principles and Procedures. Oxford: Oxford University Press.

Auby, J.-B. (ed.). (2014). Codification of Administrative Procedure. Bruylant.

Avbelj, M. (2014). Theorizing sovereignty and European integration. Ratio juris, 27(3), 344-363.

Bousta, R. (2013). Who Said There is a 'Right to Good Administration?' A Critical Analysis of Article 41 of the Charter of Fundamental Rights of the European Union. European Public Law, 19(3), 481-488.

Burgi, M. and Durner, W. (2012). Modernisierung des Verwaltungsverfahrensrechts durch Stärkung des $V w V f G$. Baden-Baden: Nomos.

Dragos, D. C. and Neamtu, B. (eds.). (2014). Alternative Dispute Resolution in European Administrative Law. Springer.

Dubos, O. (2015). The Origins of the Proceduralisation of EU Law: a Grey Area of European Federalism. Review of European Administrative Law, 8(1), 7-25.

Galligan, D. J., Langan, R. H. II and Nicandrou, C. S. (1998). Administrative Justice in the New European Democracies: Case Studies of Administrative Law and Process in Bulgaria, Estonia, Hungary, Poland and Ukraine. Oxford: Open Society Institute, Constitutional and Legislative Policy Institute and the Centre for Socio-Legal Studies, University of Oxford. European Parliament. (2001). Right to Defence and Fair Legal Procedures in the Member States and the Candidate Countries. Working paper, Brussels.

European Parliament's Resolution with recommendations to the Commission on a Law of Administrative Procedure of the European Union (2012/2024(INI)) (2013). Retrieved December 25, 2015, from http://www.europarl.europa.eu/sides/getDoc.do?type=TA\&referen$\mathrm{ce}=\mathrm{P} 7-\mathrm{TA}-2013-0004 \&$ language $=\mathrm{EN}$.

Harlow, C. and Rawlings, R. (1997). Law and Administration. London, Edinburgh, Dublin: Butterworths.

Helleringer, G. and Purnhagen, K. (eds.). (2014). Towards a European Legal Culture. Beck, Hart, Nomos.

Hofmann, H. C. H. and Mihaescu, B. C. (2013). The Relation between the Charter's Fundamental Rights and the Unwritten General principles of EU Law: Good Administration as the Test Case. European Constitutional Law Review, (9), 73-101.

Hofmann, H. C. H, Schneider, J.-P. and Ziller, J. (eds.). (2014). The ReNEUAL Model Rules. ReNEUAL. Retrieved December 25, 2015, from www.reneual.eu.

Inspection Council - Ministry of Public Administration (2015). Annual reports of the Inspection Council. Retrieved December 1, 2015, from http://www.mju.gov.si/mju.

Kelly, J. (2003). The Audit Commission: Guiding, steering and regulating local government. Public Administration, 81(3), 456-476.

Kovač, P. (2011). Modernizing administrative procedural law in Slovenia as a driving force of efficient and good administration. The NISPAcee journal, 4(2), 39-66. 
Kovač, P., Remic, M. and Sever, T. (2015). Upravno-procesne dileme 3 v posebnih upravnih postopkih [Administrative-Procedural Dilemmas 3 in Special Administrative Procedures]. Ljubljana: Official Gazette RS.

Meuwese, A., Schuurmans, Y. and Voermans, W. (2009), Towards a European Administrative Procedure Act. Review of European Administrative Law, 2(2), 16-22.

Nehl, H. P. (1999). Principles of Administrative Procedure in EC Law. Oxford: Hart.

Ortlep, R., Ouden den, W., Schuurmans, Y., Tollenaar, A., Veen van der, G. and Wolkswinkel, J. (2014). Lessons for Europe. Dutch experiences with the codification of general administrative law, EGPA conference, September 10, 2014, Speyer.

Pirnat, R. (ed.). (2004). Komentar zakonov s področja uprave [Comments to Acts relating to Administration]. Ljubljana: Public Administration Institute, Faculty of Law and Nebra. Rose-Ackerman, S. and Lindseth, P. L. (eds.). (2011). Comparative Administrative Law. Cheltenham, Northampton: Edward Elgar.

Tolsma, H. D. (2014). Improving Environmental Permitting Systems: Integrated Permits in the Netherlands, International Public Administration Journal, XII, 81-98.

Statskontoret. (2005). Principles of Good Administration in the Member States of the European Union. Retrieved December 15, 2014, from http://www.statskontoret.se/upload/Publikationer/2005/200504.pdf.

Šturm, L. (ed.). (2011). Komentar Ustave Republike Slovenije. Dopolnitev - A [Comments to the Constitution of the Republic of Slovenia - Supplement A]. Brdo: School of Government and European Studies.

Wakefield, J. (2007). The right to good administration. Kluwer Law International. 